\title{
The Invisible Hand of Rent Seeking: Capitalism, Democracy, and the Budget Deficits
}

\author{
Hiroaki Hayakawa ${ }^{1, *}$ and Yannis P. Venieris ${ }^{2}$ \\ ${ }^{1}$ Professor, School of Business and Economics, Universiti Brunei Darussalam, Brunei \\ ${ }^{2}$ Professor Emeritus of Economics, San Diego State University, and Visiting Professor, Claremont Graduate \\ University, USA
}

\begin{abstract}
Historically, social and economic grievances resulted in sociopolitical instability, which served as a medium of institutional changes in the evolution of Western Europe toward a more inclusive regime. In today's democratic capitalism, however, a great many interest groups have burgeoned and acquired political power to seek their own interest at the expense of the welfare of the general public. Interest groups thrive on a tacit agreement with those members of the political body whose primary interest lies in their own aggrandizement. Such agreement inevitably leads to excessive claims on public resources, interferes with the market system by perpetuating rent in many sectors of the economy, erodes the moral values of trust and respect, and causes moral hazard among the legislators by undermining budgetary discipline. Moreover, the inevitable friction among the legislators often results in gridlock in public decision making. The democratic capitalism thus is losing on both ends: the market efficiency and political efficacy, with reduced prospect of economic growth. This paper attempts to explain these phenomena as a strategic equilibrium of the major players in the politico-economic arena.
\end{abstract}

Keywords: Democratic capitalism, interest groups, rent seeking, economic inefficiency, political inefficacy.

\section{INTRODUCTION}

In today's world of normative pluralism, people exercise political power through their participation in groups of like-minded individuals. We call the collectivities of such individuals or the collections of firms or other private institutions that are bonded by and engaged in one or more common concerns and demands interest groups. For all practical purposes, the members of these groups and particularly their representatives are the main political agents, who develop and broker both social inclusivity and the necessary social capital to advance their causes. They also manifest the will and interests of the private sector, be it groups of individuals, firm(s), or institutions. In addition, as we shall shortly see, the size of membership and the number of interest groups as well as the amount of cultivated social capital tend to cumulate as democracy becomes increasingly inclusive. This provides them with opportunities to extract economic rent from both the public and private sectors. We observe that the majority of political decisions, on the matters of state expenditures and revenues, are greatly affected by the presence of interest groups and, as a result, competition among them for such matters becomes tighter. This is the case because the demand advanced by these interest groups, financial or not, exceeds the capacity of the state to meet it.

*Address of correspondence to this author at the School of Business and Economics, Universiti Brunei Darussalam, Brunei Darussalam, Brunei; Tel: (+673) 246 0922; E-mail: hiroaki.hayakawa@ubd.edu.bn
The purpose of this paper is to investigate the implications of democratic inclusivity, chiefly in the context of the U.S economy and society, for the Federal budget and the growth of its deficit as well as for the collateral damages that such inclusivity entails particularly in regard to economic efficiency and the equity of income and wealth distribution. Our argument begins with an observation that the needs of the members of legislative body and those of interest groups dovetail. This strengthens a tacit alliance between them, which serves their respective interests but at the expense of those of the general public. Significantly, such alliance is used as a template for the securement of their interests in new situations and has borne a symbiotic relationship that perpetuates their interests over time. One of the notable characteristics of such relationship is that a great deal of rent that this relationship yields is re-cycled into the political process. This exacerbates the already existing income inequality that threatens the institution of the free exchange economy as well as the efficacy of the democratic decision making process itself. That is, the state has fallen into the hands of powerful rent seekers who not only cultivate the circumstances of embedding their interests into favorable institutional structures but also prevent the state from solving problems that promote the welfare of the public. In the process, this alliance results in reduced economic efficiency and increased inequity of income and wealth distribution, that jointly affect economic growth and, thereby, become new sources of socio-political instability. This is important because inequality in income and wealth distribution is 
morally incompatible with the democratic ideal of social justice and could indeed become, once more, responsible for similar turmoil and resentment that caused the downfall of democracy in Europe during the 1920s and 1930s.

\section{INCLUSIVITY}

The terms inclusivity and exclusivity are evocative, ambiguous and elastic, and have been defined in more than one way. Here, we accept the definition of exclusion as the circumstances that prevent an individual from participating in aspects of the economic, social, political, and cultural life of one's society. On the other hand, inclusivity is the logical complement of exclusivity. Inclusivity is known for its stabilizing negotiative and meditative functions and powers, that is, for lack of dualities. Democracy comes with various degrees of inclusivity. It can be a full, flawed, hybrid or restricted one depending on what is missing and the degree to which it is missing. We note that the concept of inclusivity is more demanding than that of democracy. That is, inclusivity requires democracy but democracy does not necessitate inclusivity (Myrdal 1944; Young 2002; Wolbrecht and Hero 2005).

Individuals, disorganized and separated as they are from each other, are not able to acquire the political purchasing power necessary to anchor their preferences and claim their share of public resources and other favors the state can provide. It is through the bunching of individual interests into organized groups that their demands and claims become credible and successful. Such practice is rooted in democracy along with the free rider syndrome (Olson 1965). In particular, as we draw closer to a democratic civil society, organized interest groups grow considerably in number, along with growing membership and accumulation of necessary social capital to channel their claims. In time, this evolution inevitably leads to an increase in the demand for public resources and state services that eventually exceeds the supply capacity of the state.

On the other hand, groups that serve more narrowly defined interests emerge in great numbers and often acquire a disproportionately large power relative to the diffused and isolated power of individuals. Under democratic circumstances, although individual actors are vested with the right to vote, their political power is so small that their role in the public decision-making is marginalized. If collective action is hard to come by because the cost of organizing it exceeds the expected benefit, a viable alternative for individuals is to form interest groups by delineating selective incentives and to seek rent by means of the political power acquired through lobbying the political body.

The interest group proliferation consists in influencing public policy that favors their members in terms of financial benefits that end up on one or the other side of the federal budget, civil rights, or special claims and other services. What is of great interest here is that the political battlefield has now shifted from a space in which political power is more or less uniformly distributed to a space in which such power is clustered and concentrated in interest groups.

Given that the membership of political parties consists of individuals whose primary interest is to seek income, prestige, power, and the fulfillment of their ideological inclinations (Downs 1957), ${ }^{1}$ an exchange is liable to take place between them and the various interest groups ${ }^{2}$ that is, interest groups demand public resources and legislative protection of their claims, while the party in power supplies the same. There is, in other words, an implicit contract or a tacit alliance between these two groups since they both appreciate the importance of such relationship with respect to their respective goals.

Some of these claims are expressed in terms of legislative means, assignment of favorable contracts, or through similar allocations on either side of fiscal budget. Assignments of contracts or other favors that protect various actors from the vagaries of the market, however, distort the integrity of this institution by perpetuating the sources of rent while the political party in power softens the fiscal budget by extending assistance to inefficient industries, firms and organizations, thereby causing moral hazard in the

\footnotetext{
Perhaps, since Downs postulates that the primary motives of the members of political body lie in their private interests and ideology, which is, in effect, a hypothesis, we should treat it as such and attempt to resolve the ensuing debate by providing empirical evidence as to not only the variables that play a significant role in their decision making but also their relationship with each other. Unfortunately, although there is a debate concerning the factors that determine (motivate) the behavior of politicians, the relevant literature has not, as yet, provided adequate empirical evidence regarding the ranking of these variables, their relation with each other, and the overall sum of their influence that determines the final outcome of the motivated behavior. Therefore, our knowledge concerning the motivational factors, the determination of the preferential ranking of the factors that politicians take into account, the extent to which such rankings influence their political behavior, and the duration of such influence is altogether lacking as well. Yet, all these questions are of great importance in both; first, identifying the correct specification regarding explanatory variables and their nature and, second, identifying the form of the function(s) themselves. What is also of great significance is that time and place may change the functional relationships in question.

${ }^{2}$ These groups reflect the interests of business, labor, cities, farms, the poor, the rich, the employed, and the unemployed.
} 
behavior of the management and affecting the performance of the market once more (Kornai, Maskin, and Boland 2003). ${ }^{3}$ This violates the principle of fiscal discipline. Although such violation might yield some short-run benefits to specific groups or industries, these may be eclipsed by the long-run ramifications, particularly if moral hazard it invites results in changes in the behavior of the actors involved, be they individual consumers, firms, or institutions (Buchanan and Wagner 1977).

The basic problem in the behavior of interest groups lies in their tenacious self-centered demand for protection and assistance to maintain and extend their advantage(s). The outcome of this is that the market is turned into an arena of latent rent seeking opportunities and that the fiscal budget, in its hard form, is turned into a new case of the tragedy of the commons.

This tragedy has serious implications for the way democracy works. To be elected, political parties are tempted to appeal to powerful interest groups, by offering and selling policies of various forms and scope in exchange for their votes and other considerations. Individual participation in the democratic decision making is valued as the necessary condition for the survival of democracy. Unfortunately, individuals, standing alone, have only marginalized political power. They can, however, regain this power by forming interest groups, that have more focused goals and can mobilize resources to underwrite the outlays of searching for and hiring people with necessary expertise to process, interpret, and make use of available information to their advantage. Therefore, the alliance we referred to earlier takes the form of the enabler for both interest groups as well as the political body since they both have their concerns and needs satisfied. Indeed, the political body joins hands with powerful interest groups from industries, labor, professionals, and producer and consumer associations, to extend old and make new promises to potential rent seekers that serve their goals (Fotopoulos 1999; de Figueiredo and Richter 2014; Gilens and Page 2014; Drutman 2015). Furthermore, since the political parties require cooperation of the bureaucratic body, they also tend to collude tacitly with them by giving them a favorable treatment in exchange for their loyalty (Niskanen 1971).

Inclusivity and democracy as well as their evolution are also related to variables such as culture, income,

\footnotetext{
${ }^{3}$ Notice that these problems exist even under bipartisanship through logrolling.
}

and its distribution and growth. The econo-political space is divided into a number of interest groups all of which have their private alliances with members of the political body. On the other hand, the political body knows that for the smooth functioning of the state business, the consent of the various social groups is the sine qua non condition. As a matter of strategy, every interest group advances non-negotiable demands and expects to have them satisfied expeditiously. This presents a number of problems for political entrepreneurs. First, a number of the views and claims that the various factions represent and subscribe to are most likely competitive with each other. This makes it difficult for the policymakers to decide and define the national and local priorities and agendas for the future. Second, it affects the national as well as regional politics of the budget. Third, it gives rise to gerrymandering. Fourth, it affects the behavior of the judiciary and that of the bureaucrats who become more aggressive and independent. Finally fifth, it seriously affects the demeanor of the political entrepreneurs. In short, here we find the battle ground on which both capitalism and democracy parade their claims, exhibit their contradictions, project their power, and compete for supremacy.

What comes out of democracy is, therefore, a complex coalition of the shared interests mediated by the political parties and a variety of private and bureaucratic groups of interest which form a bond strong enough to place practically every aspect of policy into gridlock. One of the main characteristics of this anomaly is that the various budgetary items and claims are now complementary to each other in the sense that any flexibility that might have existed before in trading one budgetary item with another is altogether lost. ${ }^{4}$ This is because each and every interest group, along with their political allies, marshals a fierce defense in support of their budgetary item(s) and against the objections that countervailing interest groups and other powers raise. There is, thus, little substitutionability among the budgetary items in a democratic state budget. ${ }^{5}$ This outcome is diametrically opposite from the case of a budget in a despotic state. There, all budgetary items are perfect or near perfect substitutes to one another because this particular state

\footnotetext{
${ }^{4}$ Interest groups compete with each other for state favors as well as for supremacy among themselves. Weak interest groups lose in this competition for favors or other allocations to be accorded by the state.

${ }^{5} \mathrm{~A}$ similar lack of substitutionability in the case of interdependent consumer choice via reference groups has been analyzed by Hayakawa and Venieris (1977).
} 
is not intimidated by any interest group that would not even exist. On the other hand, what is disguised by this complementarity is the fact that the political body loses its ability to decide on matters of vital importance to the society.

From the standpoint of the government and the party in charge of it, interest groups are where interests are clustered with identifiable voter preferences. Hence, they can be dealt with in concrete terms. Therefore, it is in the best interest of the politicians to tap these groups, first as sources of votes that can be counted on; second, as a means of accumulating the required wherewithal that will facilitate their reelection; and third, as part of resources that will provide for their future; that is, retirement. This is an efficient way of complementing the effort of appealing to the general public through political rhetoric and framing the return, which is at best uncertain. But once those clustered interests form an association with the political body in general, and if the party in charge, in particular, successfully provides them with special treatments, democracy loses its budgetary efficacy of having flexible putty-like budgetary items. Indeed, most of the items now have turned into clay. This is, in fact, reinforced by the nature of the great majority of the budgetary items, which reflect the preferences and compromises between the political body and interest groups of the past. According to available statistics their sum amounts to about ninety percent of the U.S. federal budget. This inflexibility stems from the existing set of statutes. But the legislature could have changed this by an appropriate adverse vote(s).

The reasons why this does not happen are exactly the same as the one that established the statutory structure of the budget in the first place. The inflexibility in question is also reflected in the behavior of each and every interest group that is not willing to make any compromise when it comes to reducing its demand(s) on the discretionary part of the budget; that is, the remaining residual which amounts to about ten percent. Therefore, the budgetary items are now clay either due to statutory reasons or due to alliances between interest groups and the political body. Indeed, the ability of the U.S. democratic state to decide is lost to a great extent. The same explanation holds in the case of dated pieces of legislation which still absorb resources without any, or even trivial, present-day reason. This translates into an expanding deficit and accumulation of debt over time. The government, in other words, by supporting rent-seeking, is destined to lose its fiscal discipline by turning a hard budget into an ever softer one through an increased reliance on debt financing which reflects its inability to make the required hard decisions. The political body takes an easy way out by passing the required tax burden to future generations. In the political game played, the government procrastinates its fiscal responsibility through hyperdiscounting. The expediency of winning votes to get the monopoly of political power now necessitates it. Therefore, increases in any budgetary item, given the lack of substitutionability among them as well as the reluctance of the political body to raise tax rates, will result in corresponding budgetary deficits or increases in them. How large such deficits will eventually become depends on the interaction of the political body with the claims and the power of the interest groups.

On the other hand, whether the general public remains disinterested in policy making because of rational ignorance (Downs 1957) due to the high cost of acquiring and processing the necessary information or because of rational irrationality (Caplan 2001) makes little difference regarding the formation of such coalitions. But a political field in which rational ignorance is a dominating strategy of many agents is certainly susceptible to such formation. Yet, in the midst of uncertainty about the voter preferences and the lack of scientific evidence on the causal relationship between policies and their effects in the world of unintended consequences, it is rational for the governing party to innovate on a device of uncertainty reduction that fits their survival. This can take place through the formation of a tacit coalition among the players of shared concerns under the veil of public interest. Indeed, if the goal of a team of a political party is to seek their own interest, the democratic ideal fades away, only to be replaced by their practical strategies aiming at securing the political power to run the state, at the expense of the public interest. But rational ignorance or irrationality does not apply, for example, in the case of well informed interest groups such as the defense contractors, the pharmaceutical industry, the oil exploration companies, the agricultural sector, and the labor unions, where their successful claims amount to direct contributions made to them by the state in the form of favorable contracts, tax exemptions, outright subsidies, or all of the above. In addition, lobbying activities usually take place behind closed doors and the opaque nature of this process facilitates the decision making by the politicians and their relationship with the lobbyists. This is, in fact, what motivated Professor Stigler (Stigler 1971) to suggest that, as a rule, regulation is acquired by industry and is designed and operated by bureaucracy primarily for its benefit. 


\section{THE DOWNSIDES OF INCLUSIVITY}

In the U.S. at least, civil society, social capital, education, and pluralism contribute significantly to providing the individual actors and their interest groups with specific knowledge regarding their constitutional and statutory rights. Indeed, the success of one group is used as a template for the organization, demands, and strategies of other groups. So, the more we subscribe to and acknowledge pluralism as an expression of social and political diversity, the closer we draw to democracy and the more inclusive and divided the society becomes. This division depends clearly on the competition of the various groups for resources and rights as well as upon the ideological distance that separates each other. Democratic inclusivity entails a significant proliferation of the number of these groups, that exacerbates the variety and volume of demand for public resources, statutory rights, privileges, and other favors. Being a member of a particular group not only adds one more voice to its cause, but also increases the level of social capital among the individual members of the group and contributes to their social inclusivity. This is the case because they not only participate in the decision making regarding the claim(s), but they also share the triumphs or failures of the group. Yet, the lines of conflict among the interest groups are many and shifting as power is an everlasting bargaining process, particularly among those groups that have overlapping aspirations and targets.

In turn, this implies that as the number of the interest groups increases and the competition among them becomes stronger, the task of pleasing all of them becomes increasingly difficult, if not impossible. This problem is exacerbated because politicians themselves are as deeply divided as the interest groups they represent. Therefore, the political effectiveness of the state, along with its stability, becomes commensurably weaker. In short, the decision making of the state becomes extremely difficult and the policymakers become reticent and dubious about their choices. This is a serious problem that American democracy faces today. It is not capable of producing decisions anymore. ${ }^{6}$ In general terms, as a state becomes more democratic, its degree of inclusivity improves but its effectiveness deteriorates.

\footnotetext{
${ }^{6}$ This is only one of the shortcomings of inclusivity. To mention one more, inclusivity can potentially contribute also to discrimination. This is the case, for example, when two equally qualified candidates apply for a job, but the one
} who belongs to the same interest group as the one who examines gets it.
Indeed, as the state runs out of capacity to satisfy all the demands, there is a break down in public decision making; that is, no matter what direction the state takes, it is bound to offend some interests. This, however, is incompatible with the calculus of the political entrepreneurs. Under such circumstances, the policymakers decide either not to decide or, in the alternative, to compromise and adopt marginal policies.

What makes the task even more difficult is that all economic actors are consumers. Some are also investors as well as citizens and their behavior straddles the boundaries of their loyalties and affects their voting. Therefore, the earlier conclusion can be extended; that is, democracy in the U.S. and in particular inclusivity, are both related inversely to governability. The ability of the state to govern declines as we draw closer to democracy and inclusivity. Therefore, if inclusivity results in democratic ineffectiveness, this may very well have serious implications regarding the long-run sustainability of the democratic rule and state. ${ }^{7}$

Consider, for example, the case of Medicare and Social Security in the U.S. Given the budgetary deficits, the Republicans argue for a reduction in the benefits of these programs, but they are reluctant to act upon it because the interests that support them are very strong. On the other hand, the Democrats argue for an increase in the tax rate on the wealthy but, they too, are reluctant to trade-off tax increases on the wealthy in exchange for Medicare and Social Security reduction for similar reasons; This amounts to a grand illusion that results in and contributes to the impotency of the state.

In the past, Professor Ostrom cited evidence from experimental studies that face-to-face communications in the case of a "public good" game increase cooperation substantially (Ostrom and Walker 1997; Ostrom 2000). On the other hand, Kahneman and Tversky (1979) determined earlier, in their prospect theory, that decision makers tend to think more in terms of gains and losses rather than in terms of net assets. It follows therefore, that their calculus is predicated upon the deviation that a choice yields in relation to a point of reference which is usually the status quo. Moreover, the count of losses (disutility)

\footnotetext{
${ }^{7}$ This point is important in that, despite the revealed preference of the U.S. foreign policy to expand the democratic rule across the international landscape, the state of the U. S. democracy can no longer provide the Third World with a good example of governance.
} 
from a certain point, which is used as a reference, is larger than an otherwise equal gains (utility) because they take into account the difference in the time of possession, rather than just the resources that are needed for a particular outcome. They incorporate this asymmetry in time of possession by defining the utility function on deviations of losses and gains from the reference point in question with the additional provision that these deviations are concave for gains and convex for losses and also are steeper for losses than for gains. If the benefits that interest groups are currently enjoying are at stake, their value functions support the conclusion that it will be nearly impossible for any compromise to take place between such groups, even if the degree of communication increases by face-toface negotiations. The problem with respect to democracy is not that direct communications fail to result in cooperation, but rather that communications break down as the allocation of budgets and other special favors get locked into the system so that any downward readjustment causes frustration, mistrust, and even loss of faith in the democratic institution itself. Furthermore, institutional functional inadequacy is exacerbated by the ideological differences it breeds among the interest groups and their representatives in the political body.

When reforms are considered that make society more inclusive, economists turn to the Pareto ranking to decide the issue on objective grounds. This concept is usually applied with consequentialism in mind; i.e., how much one gets as a consequence of an effort which makes an actor either better or worse off. So, a reform designed to make a society more inclusive should benefit some people without imposing any sacrifice on others; but this is not quite enough if it ignores equity considerations. For example, if we increase the income of the rich by $\$ 100.00$ and that of the poor by $\$ 1.00$, although both are better off according to consequentialism, the distribution of both income and wealth has deteriorated in the eyes of those who received one dollar. Particularly in emerging countries, such an increase in the inequality of income distribution does not come, in the long run, without any retribution expressed in terms of sociopolitical instability (Venieris and Alcántar-Toledo 2014). Indeed, this was also the case in Europe where democracy flourished in the aftermath of the World War I but eventually faded away in less than twenty years due to sociopolitical instability that was the outcome of a rising income inequality (Mazower 1998).

What is important here is that this income and wealth inequality supports and introduces expressions of dualities that do not exist in a vacuum and characterize the whole spectrum of countries regardless of their developmental stage. Indeed, they exist in correspondence with and in reference to other dualities; like the duality in representation, the duality in legislation, and the duality in access to the centers of political, legal, economic, and social decision making and power. And these engender another set of dualities; e.g., the duality in education and its quality, the duality in gender, and the duality in opportunity, which reinforce each other over time and result in pegging many actors at the same social station for generations. In fact, the randomness of where each actor belongs at birth, and the special individuals or institutions whose consent is required for any policy, makes these dualities even more unfair, morally unacceptable, and certainly incompatible with the very concept of democracy - particularly because the levels of income and wealth are positively related with political power (Bartels 2008; Gilens 2012).

\section{THE VETO PLAYERS}

The special individuals or institutions whose consent is required for any policy change are defined as the veto players (Tsebelis 2000). They are usually designated by the constitution of a country. In the U.S., for example, these individuals are the President, the House of Representatives and its Speaker, and the Senate and its Majority Leader. Moreover, one may also include powerful lobbies that indirectly affect decision making or the lack thereof through their financial support of decision makers.

Each country has a different configuration of veto players with an identified ideological or political distance from each other. The interaction of the veto players results in the so-called winset (Tsebelis op. cit.), which consists of all policies that can replace the status quo. The size of the winset has considerable implications regarding the acceptance of the status quo or its replacement. To quote Tsebelis, "significant departures from the status quo are impossible when the winset is small; that is, when the veto players are many; when they have significant ideological distances among them and when they are internally cohesive" (Tsebelis op. cit.). In other words, if the winset includes a small number of points or no points at all, the likelihood of an agreement that significantly changes the status quo is either very small or nil. Further, those veto players that present "take or leave it" proposals to other veto players are identified as the "agenda setters" (Tsebelis op. cit.). Agenda-setting-players, like other 
veto players, have to make proposals that are acceptable to all. In fact, the optimum selection implies that they will select what they prefer most among all possible feasible outcomes. As a result, "agendasetting" powers are inversely related to policy stability; that is, the higher the policy stability (meaning the smaller the set of outcomes that can replace the status quo), the smaller the role agenda setting (plays)" (Tsebelis op. cit.). In the case in which the winset is empty so that any departure from the status quo is impossible, agenda setting plays no role.

There are a number of significant conclusions that can be derived from the theory of veto players. The one that is of greatest interest here is that Tsebelis' empirical analysis confirms that policy stability is a function of the number of veto players "not only when one focuses on legislation (i.e., legislative instruments), but also when one studies macroeconomic policies (i.e., legislative outcomes)" (Tsebelis op. cit.). Under these circumstances, policy instruments are rendered obsolete and new policies are difficult to be initiated. The theoretical and empirical work of Tsebelis confirms our earlier assertions that policymakers can no longer decide or control the budget and its deficits.

On the other hand, the concept of stability is used in two ways. One is the stability which is partly due to an increasing number of veto players. In this case, the legislative body cannot agree on policies even if it wants to change the status quo. Hence, it cannot cope effectively with problems facing the state. Stability of this kind breeds mistrust in the leadership of the governing party and sociopolitical instability. The other form of stability reflects a flexible capacity to meet contingent problems with effective policies, which is what is needed to keep the economy thriving.

Tsebelis' analysis of veto players is a useful way of explaining the working of political institutions in terms of veto players, winset, and the core. ${ }^{8}$ As we argued

\footnotetext{
${ }^{8}$ Tsebelis's analysis, or, for that matter, Hammond and Miller's (Hammond and Miller 1987) are quite abstract, leaving unclear the nature of the space on which the preferences of the players are defined. In particular, the question is: when one deals with the status quo and the indifference curves passing through the point representing this state and with the winset of the veto players containing some alternatives, what is the underlying space on which they are defined? If a change in the status quo is represented by a movement from a status quo point to another point in the winset, the question is, in effect, what has been changed by this move. If policies are what we have in mind, we know that they cannot be represented by points in space. If the consequence of policies is represented, then it begs a serious question as to what the relationship is between policies and their consequences. This is a difficult question to answer since the relationship is not one of simple linear causality. At any rate, we take their analysis as a heuristic one, which serves to derive heuristic propositions from heuristic analysis. Our analysis takes this space to be the space of all possible states.
}

earlier, if society is divided into numerous interest groups and if their interests are represented by veto players, their winset diminishes, thereby depriving the legislature of its ability to meet the call of governance. There is, however, another dimension of the problem which is not fully addressed by the literature although it is very relevant to our investigation. This is the case in which the preferences of the veto players represent only the concerns of the interest groups instead of the concerns of the public-at-large.

\section{WELFARE AND GROWTH CONSIDERATIONS}

If the status quo is broken because of the actions of the veto players, the country is normally expected to move to a more desirable state. If, however, an increasing number of interest groups emerges through the logic of collective action á la Olson and, if the primary purpose of these groups consists in rentseeking by using the protective services provided by the members of the political body including the veto players, then the changing of the status quo by the veto players may greatly compromise the efficiency of the economy and its growth potential. Furthermore, from a dynamic standpoint, when, at one stage, the status quo is changed by the action of the incumbent veto players, through some collusive agreement or logrolling, to some interior point of the winset, this new point becomes an initial condition for subsequent stages and defines, therefore, a new status quo and a new winset for the new veto players who come to replace the old ones. The preferences of the new veto players differ from those of the old, but as long as the veto players represent the interest of the rent-seeking groups, a change of the status quo mediated by their action shifts the state of the economy further away from where it could be without their influences. This is the case because the new veto players must add more favorable treatments to what the old ones have already provided, in order to maintain their power and income.

This was also Olson's concern; namely, that the mushrooming of interest groups over time seriously compromises the dynamic growth of the economy as it becomes less and less efficient. Collective goods for the society as a whole are hard to come by, whereas more narrowly defined collective goods that benefit only those group(s) that share a common interest are far easier to come by through selective incentives. If the socio-economic space is characterized by the clusters of group-centered interests, it is only natural for the players of the political game to tap on such interests as the sources of their power and income; that 
is, to turn themselves into the potential sellers of favors and protection in exchange for campaign contributions and other benefits. Downs' assumption (Downs 1957) that a political party is run by a team of people who seek income, prestige, and power that goes with governing, and Olson's logic of collective action for smaller groups, as well as Tsebelis' analysis of political stability in terms of the preferences of the veto players, taken together, show how a tacit coalition among politicians, interest groups, bureaucratic offices, and the veto players may be formed and work as a cumulative negative causation on the efficiency of the free capitalist economy.

To the extent that democracy is a fertile ground for breeding these alliances, it follows that when democracy and capitalism attain advanced levels of development, they are no longer supportive of each other. Indeed, the prevailing ideology of the combative ethic of Laisez-faire and individualism, along with the implied social Darwinism, or more generally, the ethic of capitalism, as well as, on the other side, the aggressive factionalism and near-sightedness of the political body in the U.S. and many other countries in the West, have brought about a serious incompatibility between these two institutions. To put it differently, capitalism resents any impediments democracy erects in its way and, in its effort to free itself from them, responds in ways that compromise democracy's integrity and effectiveness. In short, although their union was presumably made in heaven, unfortunately, they are now in need of marriage counseling.

It is ironic that Schumpeter's concern that the dynamism of capitalism wanes with the loss of the spirit of entrepreneurship comes to haunt us again through the apathy surrounding the erection of a multitude of walls, which guard the rent of interest groups by the hand of politicians, who busy themselves with their own commerce of favorable treatments of income and votes. Once the political mechanism is in place to channel the voice of the narrow interest groups into legitimate devices of special treatments and statutes, the state faces an almost impossible task of keeping these groups from dominating policymaking (Olson 1993). What is also interesting about this is that, until recently, Western Europeans have been far more sensitive about such public policy indiscretions than Americans. Indeed, the English, French, and German public and their unions are far more ready to engage in acts of socio-political instability (e.g., protest demonstrations), if and when such indiscretions come to their attention, and to demand appropriate public policy.

Schematically, Diagram 1 below, which is drawn in the space of all possible states, shows the case of two veto players. The social welfare function, defined on this space, is represented by its indifference curves. The status quo point in this space defines the initial state of the veto players. Their winset is shown by the intersection of the upper contour sets of their indifference curves passing through this point. The veto players attempt to choose the best policy option that changes the status quo. Since their preferences are derived from their desire for aggrandizement in income and power, and driven by an inclination to act in the interest of certain interest groups, they do not coincide with the social welfare function. The winset is either a singleton set containing only the status quo point $\mathrm{S}$, or more than a singleton set because the indifference curves cut into each other, so that the upper contour sets of the two players have an intersection covering a more extensive area that includes S. If the veto players are motivated only to act for the benefit of their interest group clientele, the winset will always be located in the lower contour set of the status quo with respect to the social welfare function. This implies that, if the veto players agree to act in order to change the status quo, the ensuing move may yield rent for their clients, but it will definitely reduce the social welfare by making the market less efficient. Hence, a particular measure the veto players favor will normally take the economy to a state inferior to the initial status quo.

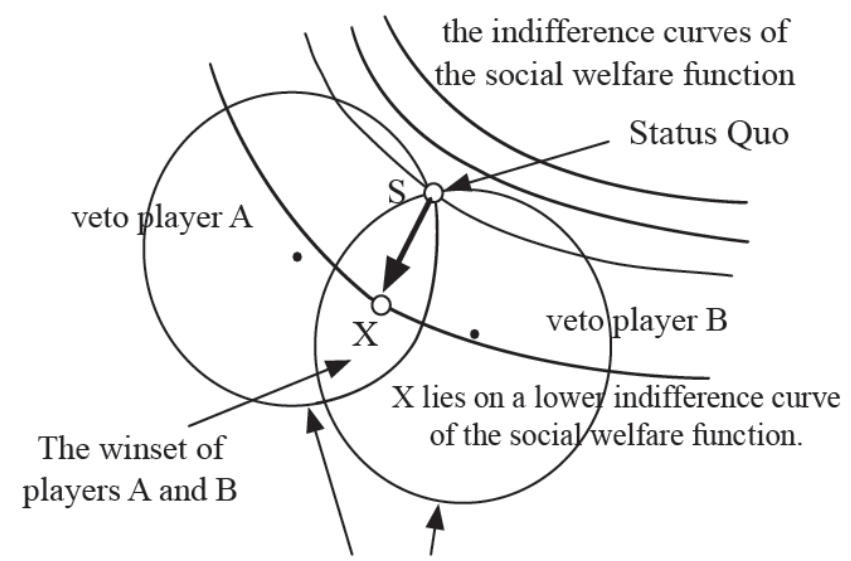

The indifference curves of the veto players passing through the status quo point $\mathrm{S}$

Diagram 1: An agreed-upon movement from the status quo (S) to a point $X$ in the winset of the two veto players makes the society worse off.

Whatever is selected by incumbent veto players defines the status quo for subsequent veto players, 
whose preferences represent the concerns of another set of interest groups, and their favorite policy measures will reduce the social welfare even further. As a result, veto players leave a trace of a rent-causing path over time as interest groups increase in number and learn how to perpetuate their rent at the expense of the social welfare.

In other words, there is an implicit dynamic process of cumulative causation in which new interest groups come into being, who keep soliciting their contemporary politicians for protective measures. The rent-seeking is a dynamic phenomenon. It goes on indefinitely into the future, and the veto players also turn over from one generation to the next. The rentseeking cumulates as new groups are born and new politicians seize opportunities for their aggrandizement through their quid pro quo transactions with such groups. Every time the veto players, old or new, act in favor of their interest group clientele and agree to change the status quo, the move reduces the social welfare.

In Diagram 2 below, we schematically show that when the veto players, $C$ and $D$ (they could be new players or the same players, $A$ and $B$ ), make a move from $X$ to $Y$, this entails the reduction of the social welfare even further. The status quo for players $C$ and $D$ is a state that players $A$ and $B$ agreed to make happen. Point $Y$ now becomes the status quo for players $E$ and $F$ (they could also be $C$ and $D$, or $A$ and $B)$ and, if they agree to change the status quo, a new state $Z$ will be reached, which will be lower again in the social welfare scale. We make this point because rentseeking (by an increasing number of interest groups soliciting favors from politicians regardless of whether they are veto players or not) is a dynamic process of cumulative causation that sacrifices the level of social welfare for the benefit of interest groups. It should also be added that to raise money and campaign contributions, politicians are always looking for new sources of income, which explains why they are willing to respond to the pressure of new interest groups (Wolfinger 1972). Just as stores welcome new clients, politicians welcome new clientele, who can provide them with campaign contributions, income and improved prospects for retirement. Both of them are rent-seekers; that is, politicians who use their political power as a source of present and future income and aggrandizement, and interest groups that use politicians to erect a legitimate wall that protects their interest. Legitimacy is a key to this rent-seeking (Kurer 1993). Their practices have become a prevailing culture today, which was recently indirectly sanctioned also by the U.S. Supreme Court in the context of the decision Citizens United $v$. Federal Election Commission.

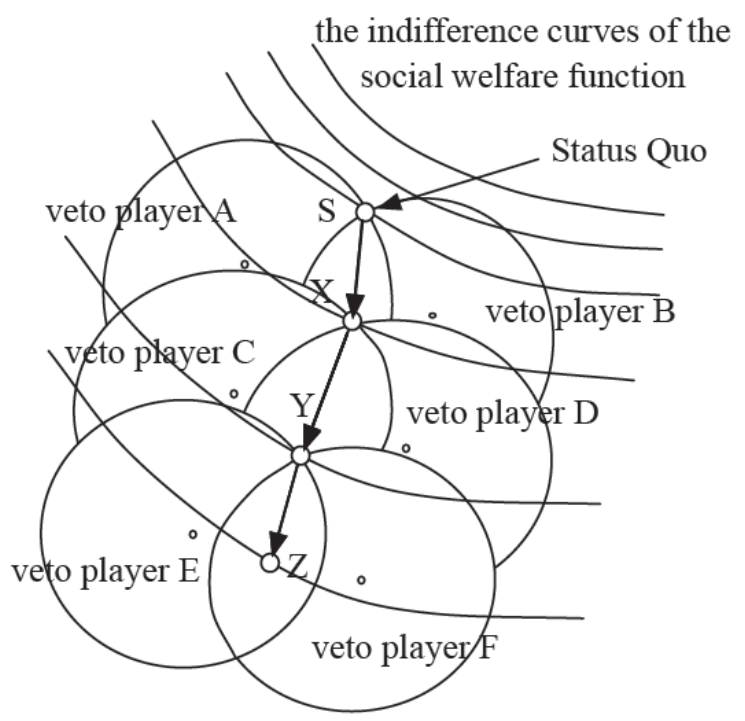

Diagram 2: A dynamic process of cumulative causation of rent seeking mediated by agreement between veto players.

As long as the veto players are motivated to protect the concerns of interest groups, the economy is destined to move further and further away from the competitive state, i.e., a rent-free state. If the veto players are many, the winset may become empty, but this does not keep them from playing a strategy of logrolling or from finding some other way to cooperate with other players. This result is obtained because the veto players, who represent the concerns of interest groups, do not care much about the efficiency of the economy, which, in turn, implies that they will seize every opportunity to collude no matter how costly it is to the economy-at-large.

Here we find again, the incompatibility of capitalism with democracy or, more precisely, with inclusivity, which manifests itself first as the enabler of interest groups and second with their frequency and numbers that keep increasing as we draw closer to democracy. In particular, if we leave this mechanism alone to its own devices, the economy will register increasingly and continuously smaller rates of growth due to interplay of the political body with the interest groups, and the decreasing efficiency that this entails. Assuming a steady state, what supports economic growth in advanced economies is the presence of technological changes. This, however, may or may not produce a net positive growth in view of the loss in economic efficiency due to the actions of the alliance between the 
political body (and in particular the veto players) and interest groups. This, however, is not the case in emerging economies since they can counter inefficiencies through the adoption of technologies that can be purchased in the international market and also since the earlier conclusion assumes a steady state. On the other hand, these states have alternative ways of reducing their efficiency such as open corruption and abuse, as well as the corresponding sociopolitical instability that this entails - all of which result in reduced growth (Venieris and Gupta 1983; Alesina et al. 1996; Venieris and Alcántar-Toledo 2014).

Earlier, Avener Greif (1994) showed how equilibrium selection comes about under the influence of cultural beliefs. For this, he studied two historical cases; one about the Maghribi traders of the eleventh century from the Muslim world and the other about the Genovese traders of the twelfth century from the Latin world. His interest was aimed at the question: "Why do societies fail to adopt the organization of more economically successful ones?" Certainly, equilibrium selection raises many interesting questions, as it results as a consequence of many institutional factors (including customs, habits, socio-cultural norms, and legal arrangements) interacting à la Myrdal (1957). This process of interaction implies that equilibrium is not something that can be chosen simply from a set of equilibrium strategies. Moreover, it raises an interesting issue; which is: why, in an advanced nation like U.S., where free choice by individuals is the foundation of its society, some of the institutional arrangements that are supposed to be the core of the nation, succumb to the pressure of interest groups that attempt to perpetuate their rent by legitimizing it.

The market, as an institution that prohibits rentseeking through legal means, performs much better than the one that is more receptive to rent-seeking. This suggests that each society has multiple equilibria and which equilibrium prevails eventually depends on what is allowed and what is not allowed as legitimate means of competition. The degree of substitutability in the government budget certainly depends on the equilibrium selected. It appears that the democratic institution selects its inferior equilibrium through a process of cumulative causation. This must have been the fundamental concern of Mancur Olson; that is, a well-developed economy could stagnate indefinitely as a result of cumulative causation in which rent-seeking by interest groups distorts the functioning of the market. This comes about through the logic of collective action where the lack of enough collective action, as a by-product, breeds the formation of small groups based on selective incentives that eventually develop into full-blown interest groups.

A nation is a club, in that non-members are excluded from its collective benefits, and it will be subdivided into a multitude of small groups or clubs by way of selective incentives - each seeking protection of the benefit(s) of its members. Buchanan's theory of clubs (Buchanan 1965) blends with Olson's insight that rising interest groups can cause a decline in economic activities, hence stagnation, and eventually can result even in the fall of a nation. There are two ways of getting rent; one is through innovative activities, and the other through formation of interest groups. The former is the source of economic prosperity and works as quasi-rent that dissipates with new innovations. The latter tends to perpetuate rent and can be a serious cause of a decline of a state through the negative externalities it generates on the efficiency of its economy.

Another point to be made in regard to the growing number of interest groups with increasing political power is that such cultural traits will be transmitted to future generations by shaping and making available templates for future references and by distorting or localizing universal moral values. If the rent-seeking becomes business as usual and, if agents' efforts are targeted at creation of rent through formation of interest groups that seek to legitimize whatever means they choose, those who are left out will lose much of their potential profits and will be forced to engage in similar tactics. This race necessitates instilling of such values that are required to rationalize the practices, which will breed mistrust and disrespect and will beget a new mentality that shows a much stronger inclination to favor insiders at the expense of outsiders. Selective incentives are used to capture the idea of soliciting members to secure the rent, but the mentality that goes with it is not pro-social; it is rather anti-social. Tabellini on institutions and culture (Tabellini 2007), along with the economics of cultural transmission (Bisin and Verdier, 2001), looks into the causal relationship between generalized values (e.g., trust and respect) and even language traits (the first person pronoun dropout) and the development of well-functioning institutions over the history that spans ages. This reminds us of Bastiat's insights and admonishment regarding the danger of legal institutions becoming instruments of using or abusing justice with the attendant consequences on economic growth, development, and social welfare (Bastiat 1850). 
What a society experienced many ages ago is transmitted through the values and cultural traits acquired then, and shows up in the kind of institutions with their respective restrictions - that we observe today. While this sort of inquiry into the socio-cultural evolution of institutions leads to more questions than answers, it, nevertheless, serves to warn us that the loss of such generalized values as trust and respect may take a heavy toll on the moral values we need to flourish. Without such values, the market economy, as an efficient allocator of resources, and the society, as a cohesive system of functions and statuses through its division of labor, becomes dysfunctional (La Porta et al., 1997; Temple and Johnson 1998; Zak and Knack 2001).

Public trust in the government and the democratic institution itself is essential for the working of a democracy. Unfortunately, the political game that goes with this institution has become very divisive, particularly, with the formation of strong interest groups and with the loss of genuine interest in public business on the part of politicians. The values on which such practices are based are local and narrow-minded to say the least. Politicians may be prudent in their effort to maximize their self-centered interest. As Downs pointed out, however, the price we pay as a society for the presence of interest groups and their interface with the political body is immeasurable. Indeed, while people think democracy is desirable, they also think that its administration is woefully inadequate, and this might very well have serious attendant consequences indeed.

\section{CONSEQUENCES AND CONCLUSION}

So far we have identified two different reasons why policy making is a very difficult task. There are two ways to look at this inability of democracy to effect changes. The first is to conclude that democracy is stable in the sense that it supports the status quo and can perpetuate in this manner for some time. In this case, however, the kind of stability that the democratic rule implies is the one in which one should not expect any fundamental change in any policy. History suggests that the life expectancy of such a regime is rather limited and several forms of sociopolitical instability will give birth to various reforms that will last until a new equilibrium will provide the required pause to socioeconomic, political and institutional evolution. The second way to look at this inability is to recognize that it is deep and structural and, conceivably, calls for a new social, political, economic, and institutional compact.
In this spirit, there is only one way left that would foster decision making, namely, to increase the power of the executive branch of the state so that the governing party enjoys a unified front during parliamentary deliberations and voting. Under normal circumstances, the increase in the executive power can reduce the number of veto players while curtailing the demands of all political, social and economic interest groups, which, combined, have negative cumulative impact on economic growth. This requires and demands the alignment of all votes of a party's members to support the program of the party. A prime minister with a parliamentarian majority has more power to enact such a program than an American president. In the parliamentarian system, not only the prime minister is the undisputed leader of the governing party, but also the representatives in the majority know that, if they do not support the prime minister in passing a particular piece of legislation, the parliament may get dissolved and they may have to be renominated and reelected. On the other hand, their renomination is predicated upon their loyalty to the views of the prime minister. This invites strong discipline among the members of the majority party (Lakoff 1996). But, it should be mentioned that a sheer increase in the executive power of a parliamentary system may turn into a new source of socio-political instability if it neglects the voice of minority groups, although a similar criticism may also be directed against the executive power of a presidential system if this power is abused. It is equally useful to note that the presence of veto players, in the American political institution for example, may serve to check the excessive use of the executive power.

The other way of increasing the executive power is to accept an autocratic regime. This raises the question about the sustainability of the democratic system. Although the nature of the above two solutions regarding governance is not the same, unfortunately, the conclusion is the same; that is, less democracy yields more governability and conversely.

Nevertheless, although "guardian states" like Singapore, China and Iran may be able to make decisions more expeditiously than democratic ones, there is a trade off between the facility in the decision making and the presence of elite corruption as well as the frequent and undeniable suppressions of dissent and other expressions of freedom.

Earlier we concluded that the rent-seeking by the various interest groups along with the associated 
activities of the members of the political body has detrimental effects on the macroeconomic efficiency. This results in a downward shift of the production function and a negative impact on the tax revenues. Given our comments about the complementarity of the budgetary items, provided that the state is concerned about its deficits, it follows that either the tax rate will have to increase or the budget will have to decrease or both. Otherwise, the budget deficit will increase. But there is adequate empirical evidence that confirms that sociopolitical instability increases when tax increases and spending decreases, and when income distribution deteriorates (e.g. Venieris and Alcántar-Toledo 2014). This was precisely what happened in Great Britain in 1989 that caused the political demise of Prime Minister Margaret Thatcher. Indeed, her attempt to levy a per capita tax (Poll Tax) while, at the same time, proposing a reduction in social spending, failed and she was forced out of the office by the extensive demonstrations of the body politic as well as the political body. ${ }^{9}$

The inability of the political body to decide has also serious repercussions on the behavior of the courts and public servants, and has, implicitly but de facto, broadened the range of their jurisdiction. Since Congress is unable to provide guidance, the courts as well as the public servants are forced to decide on issues that clearly lie outside their jurisdiction. The inability of the political body of the state to decide is tantamount to abdication of their duties. Under these circumstances, the governing party turns soft on debt financing, which is now treated as a normal way of handling the deficit.

The rent seeking by interest groups joins hands with rent seeking by politicians with no moral qualm about it because both parties benefit from this arrangement. This is indeed a Nash equilibrium of their strategies. The judicial activism adds to this rent-seeking environment by institutionalizing what is legitimate and what is not, which intensifies the lobbying activities of the interest groups. The personhood defined by the U.S. Supreme Court initiates a new game because political contributions by corporations are made legitimate. The bureaucratic activism is another element that allows the bureaucracy to act more expediently with more discretion in its hand, at the neglect of the public interest, since the role of

${ }^{9} \mathrm{~A}$ poll tax is a fixed amount per capita that is in principle regressive and contributes to increases in income inequality. Mrs. Thatcher resigned on November 22, 1990 under the pressure of intensive protests due to these grievances.
Congress is marginalized when it comes to decision making on many issues. All in all, what is interesting is that, due to the implicit alliances or understandings among the various parties involved, there is plenty of opportunity for rent-seeking by a number of actors. The unfortunate conclusion from all this is that there is not any incentive for moving away from the status quo of this equilibrium.

Thus, (1) the effects of inclusivity on the ability of democracy to decide in the U.S., (2) the rational ignorance that prevails among the public, (3) the rising power of interest groups and their strategies to perpetuate their rent through legitimization, (4) the politicians' expedient strategies to sell these groups favors in exchange for their votes and contributions, (5) the inability of Congress to act in the interest of the general public (which is a by-product of the preoccupation of the representatives and senators with the quid pro quo commerce with their clientele of interest groups), (6) the resulting inability of the political body to harness the budget and its deficits that have become structural, (7) the institutional functional inadequacy that is exacerbated by the ideological differences it breeds among the interest groups and their representatives in the political body, (8) the rising activism of the Supreme Court in institutionalizing a new rule in the political game, (9) the greater concentration of discretionary power in the hands of the bureaucratic offices to fill the hole left by the inactivity of Congress, (10) the change in attitude toward deficit financing and debt accumulation (which softens a hard budget by delaying fiscal responsibilities and reduces the efficiency and growth of the economy), (11) the inequality in the representation of concerns of the poor versus those of the elite interest groups, or, more generally the increase in the presence of domestic dualities, (12) the increased reliance on monetary policy that increases the systemic risk of financial crisis, (13) the spreading apathy and a shift in the moral values of trust and respect among the general public as distributions in income, wealth, and political representation become increasingly skewed, which only feeds the attitude of indifference already prevalent through rational ignorance, (14) the increases in the income and wealth inequalities that these rents entail and support in the various societies, and last but not least (15) the germination and growth of rent seeking that results in economic inefficiency and reduced growth and gives rise to sociopolitical instability, all of these factors interact to set off a process of cumulative causation that ends up corroding the middle class, 
bifurcating, at least, the U. S. society into two extreme classes, and deteriorating the overall quality of living and public welfare, until the trend is reversed and a new overall equilibrium arrives through the electoral process. $^{10}$

Significantly, interest groups, the representatives of Congress, the Supreme Court, and the Bureaucracy appear as if they were all guided by the invisible hand of rent-seeking. In a capitalistic economy, profit seeking serves as an invisible hand, but now groups of individuals seek to find ways of getting rent from this market. Because rent disappears in a competitive market, they seek rent by erecting legitimate artificial barriers. Therefore, lobbying by interest groups, the politicians' strategy of aggrandizement through a tacit collusion with such groups, the Supreme Court's strategy to institutionalize a new rule in the arena of the political game, the Bureaucracy's strategy to increase its discretionary power, and the general public's strategy of ignoring the political game, constitutes a grand equilibrium of their self-centered strategies. Interest groups that are lobbying know what the politicians want for their power and aggrandizement. Likewise, the politicians know what interest groups want to attain by lobbying. Rent that interest groups seek, however, is in conflict with the interest of the general public because it interferes with the market system. But, an impasse on those issues of public concern allows the representatives to focus their efforts on quid pro quo with interest groups. To the extent that rents increase as we move away from the competitive market, it follows that politicians would favor an increased distance between actual and competitive markets, and, indeed, their actions contribute to this distance.

The Supreme Court, facing the failure of Congress to act and the activism of interest groups, institutionalizes a new rule by redefining the basic concepts such as personhood and rights, which reinforces the rent-seeking activity of interest groups and the Congress, while the general public takes a back seat and suffers a loss in the level of their welfare. Given the strategies of interest groups, the representatives, and the Supreme Court, the bureaucracy assumes a strategy of enhancing its discretionary power in administering its duties and functions. If Congress cannot deliver its decisions on

\footnotetext{
${ }^{10}$ Gerrymandering, of course, is also one of the negative factors that contribute to this cumulative causation.
}

matters of importance to the general public, the bureaucracy assumes the strategy of strengthening its discretionary power that widens the scope of its administrative duties and responsibilities, which is what they want. ${ }^{11}$ By doing so, they expand their power of administrative control over the economy and the society and escape the risk of being streamlined. Thus, judicial and bureaucratic activism can be viewed as the best responses to the condition of active rent-seeking and aggrandizement on the part of Congress and interest groups, which creates a vacuum in the decision making of the state.

All these problems have a negative influence on the interface of democracy and capitalism leaving, thereby, a measurable gap between them that provides an opportunity for populism to grow. To be sure, the increased level of inclusivity and the dynamic engagement of capitalism have to be, in the final analysis, measured up and compared to the increasing level of democratic and economic dysfunctionalism. That is, a society that is characterized by these interacting factors will bear the consequences of diminished efficiency of the market system, increases in inequality in income distribution, and diminished efficacy of democracy. All these, in turn, will yield losses in economic growth and welfare, and will breed social and political instability that ultimately could lead to increases in the likelihood of the arrival of populism.

To summarize the point more generally, the reduction in the three measures of performance of democratic capitalism; namely, the efficiency of the market system, the efficacy of political decision making, and its growth capacity, is an equilibrium phenomenon of a grand game played by (1) the constituents, (2) the interests groups, (3) the expedient politicians, (4) the bureaucratic offices of the government, and (5) the judiciary. The equilibrium outcome we have outlined seems to be inevitable given the adopted implicit and explicit rules of the game. If the outcome is rulespecific, then it begs another question; what are the rules that yield a better outcome?

\footnotetext{
${ }^{11}$ It is worth noticing, that successful rent-seeking under the auspices of legal institutions or bureaucratic activism, introduces more reasons for income inequality. A dramatic example of this is the income of hedge fund managers and traders who are allowed on the basis of a bureaucratic decision (i.e. no bill has been voted on this issue) to redefine their income as capital gain, thereby, subjecting it to a $20 \%$ tax rate as opposed to the regular $39 \%$. This approach was adopted as a general administrative rule by IRS in 1993 and again in proposed regulation - but not in a corresponding bill - in 2005. Closing this tax loophole would increase the federal tax revenues by an amount in the range of $\$ 1.8-\$ 18.0$ billions per year (Owen 2015). It is worth paraphrasing, in this case, Bastiat; that is, for a regulation to be respected it should be respectable.
} 


\section{POLICY RECOMMENDATIONS}

The overall conclusion of our work is that first, the economic, political, social, and institutional problems that the U.S., in particular, faces currently are structural; second, that the budgetary deficits are not the unique outcome of different ideological inclinations and perceptions; and third, that we do not need a different general social compact, in the form of a new constitution, to take care of these issues. Indeed, a great deal of the problems we have analyzed can be taken care of, first, if an upward limit is placed on political contributions by individuals, firms, or other institutions, to a level that is commensurable with the meaning of democracy; that is, to an amount that an average citizen can afford to contribute to members of the political body, along with a rule that firms may not contribute any amount to non profit institutions, which, acting like Trojan horses, purports to support elections; second, if a limit is placed on the overall level of time allotted for election campaigns regardless whether they are for persons or whole parties; third, if a rule is instituted that elected officials, public employees, and administrative appointees are all prohibited, for a period of time considered adequate, from accepting employment in the same private sectors they dealt with during their tenure, regardless of how long their employment or service with the state has lasted; fourth, if the political body legislates an explicit and clear definition of personhood that relates only to real persons and citizens. Such a bill or interpretation of constitution is necessary to improve the American public welfare, sustain the democratic system, foster economic growth, improve income and wealth distribution, and discourage populism.

\section{ACKNOWLEDGEMENT}

The authors wish to acknowledge Professors Paul J. Zak of Claremont Graduate University, Sanford Lakoff of UCSD, George Tsebelis of the University of Michigan, and Stavros Drakopoulos of the University of Athens, Greece, for their useful comments and suggestions. The authors also acknowledge the anonymous referee of this journal for his suggestions.

\section{REFERENCES}

Alesina, Alberto, and Roberto. Perotti. 1996. "Income Distribution, Political Instability and Investment." European Economic Review 40(6): 1203-1228. https://doi.org/10.1016/0014-2921(95)00030-5

Avner, Grief. 1994. "Cultural Beliefs and the Organization of Society: A Historical and Theoretical Reflection on Collectivist and Individualistic Societies." Journal of Political Economy 102(5): 912-950.

https://doi.org/10.1086/261959
Bartels, Larry M. 2008. Unequal Democracy: The Political Economy of the New Guilted Age. Princeton, N.J: Princeton University Press. https://doi.org/10.1515/9781400883363

Bastiat, Frederick. [1850] 1998. The Law, trans. by Dean Russell with introduction by Walter Williams and foreword by Sheldon Richman, New York: Foundation of Economic Education.

Bisin, Alberto, and Thierry Verdier. 2001. "The Economics of Cultural Transmission and the Dynamics of Preferences." Journal of Economic Theory 97(2): 298-319. http://doi.org/10.1006/jeth.2000.2678

Buchanan, James M., and Gordon Tullock, 1962. Calculus of Consent: Logical Foundations of Constitutional Democracy, Chapter 19: 286-87. Ann Arbor, Ml: University of Michigan Press. https://doi.org/10.3998/mpub.7687

Buchanan, James M. 1965. "An Economic Theory of Clubs." Economica, New Series 32(125): 1-14. https://doi.org/10.2307/2552442

Buchanan, James M., and Richard E. Wagner. 1977. Democracy in Deficit: The Political Legacy of Lord Keynes. New York: Academic Press.

Caplan, Bryan. 2001. "Rational Ignorance versus Rational Irrationality." Kyklos 54(1): 3-26.

Davis, Owen. 2015. "What Is the Carried Interest Tax Loophole?" Wall Street Journal, 16 September.

de Figueiredo, John M., and Brian K. Richter. 2014. "Advancing the Empirical Research on Lobbying." Annual Review of Political Science 17(1): 163-185. https://doi.org/10.1146/annurev-polisci-100711-135308

Downs, Anthony. 1957. An Economic Theory of democracy. New York, NY: Harper and Brothers. https://doi.org/10.2307/2127236

Drutman, Lee. 2015. The Business of America is Lobbying: How Corporations Became Politicized and Politics Became More Corporate. New York: Oxford University Press. https://doi.org/10.1093/acprof:oso/9780190215514.001.0001

Fotopoulos, Takis. 1997. Towards an Inclusive Democracy. London and New York: Cassell.

Gilens, Martin. 2012. Affluence and Influence: Economic Inequality and Political Power in America. Princeton, N.J. Princeton University Press. https://doi.org/10.1093/poq/nfu064

Gilens, Martin, and Benjamin I. Page. 2014. "Testing Theories of American Politics: Elites, Interest Groups, and Average Citizens." Perspectives on Politics 12 (3): 564-581. http://doi.org/10.1017/S1537592714001595

Hammond, Thomas H., and Garry J. Miller. 1987. "The Core of the Constitution." American Political Science Review 81(4): 1155-1174.

https://doi.org/10.2307/1962583

Hayakawa, Hiroaki, and Yiannis P. Venieris. 1977. "Consumer Interdependence via Reference Groups." Journal of Political Economy 85(3): 599-615. https://doi.org/10.1086/260585

Kahneman, Daniel, and Amos Tversky. 1979. "Prospect Theory: An Analysis of Decision under Risk." Econometrica 47(2): 263291. https://doi.org/10.2307/1914185

Kornai, Janos, Eric Maskin, and Gerald Boland. 2003. "Understanding the Soft Budget Constraint." Journal of Economic Literature 41(4): 1095-1136. https://doi.org/10.1257/002205103771799999

Kurer, Oskar. 1993. "Clientelism, Corruption, and the Allocation of Resources." Public Choice 77(2): 259-273. https://doi.org/10.1007/bf01047869

La Porta, Rafael, Florencio Lopez-de-Silanes, Andrei Shleifer, and Robert W. Vishny. 1997. "Trust in Large Organizations." AEA Papers and Proceedings: 333-338. 
Lakoff, Sanford. 1996. Democracy: History, Theory, Practice. Boulder, $\mathrm{CO}$ and Oxford: Westview Press.

Mazower, Mark. 1998. Dark Continent: Europe's Twentieth Century. New York: Vintage Books.

Myrdal, Gunnard. 1957. Economic Theory and Underdeveloped Regions. London: Duckworth.

Myrdal, Gunnard. 1944. An American Dilemma: The Negro Problem and Modern Democracy. New York: Harper \& Bros.

Niskanen, William. 1971. Bureaucracy and Representative Government. Chicago, IL: Aldeine-Atherton.

Olson, Mancur. 1965. The Logic of Collective action: Public Goods and the Theory of Groups. Cambridge, MA: Harvard University Press, 1965.

Ostrom, Elinor, and James Walker. 1997, "Neither Markets Nor States: Linking Transformation Processes in Collective Action Arenas." Pp. 35-72 in Perspectives on Public Choice: A Handbook, edited by D.C. Mueller. Cambridge: Cambridge University Press.

Ostrom, Elinor. 2000. "Collective Action and the Evolution of Social Norms." Journal of Economic Perspective 14(3): 137-158. https://doi.org/10.1257/jpe.14.3.137

Stigler, George. 1971. "The Theory of Economic Regulation." Bell Journal of Economics and Management Science 2(1): 3-21. https://doi.org/10.2307/3003160

Tabellini, Guido. 2007. "Institutions and Culture." Presidential lecture presented at the Meetings of the European Economic Association, Budapest, August. Published in Journal of the European Economic Association 6(2-3, 2008): 255-294. https://doi.org/10.1162/JEEA.2008.6.2-3.255
Temple, Jonathan, and Paul A. Johnson. 1998. "Social Capability and Economic Growth." Quarterly Journal of Economics 113(3): 965-990. https://doi.org/10.1162/003355398555711

Tsebelis, George. 2002. Veto Players: How Political Institutions Work. Princeton, NJ: Princeton University Press.

Venieris, Yiannis P. and Dipak K. Gupta. (1983). "Sociopolitical and Economic Dimensions of Development: A Cross-Sectional model." Economic Development and Cultural Change, 31(4), 727-56. https://doi.org/10.1086/451355

Venieris, Yannis P. and Javier Alcántar-Toledo. 2014. "Fiscal Policy, Growth, Income Distribution, and Sociopolitical Instability." European Journal of Political Economy (June): 315-331. https://doi.org/10.1016/j.ejpoleco.2014.03.002

Wolbrecht, Christina and Rodney E. Hero, eds. 2005. Politics of Democratic Inclusion. Philadelphia, PA: Temple University Press.

Wolfinger, Raymond E. 1972. "Why Political Machines Have Not Withered Away and Other Revisionist Thoughts." Journal of Politics 34(2): 365-398. https://doi.org/10.1057/9781137289056.0008

Young, Iris Marion. 2002. Inclusion and Democracy. New York: Oxford University Press. https://doi.org/10.1093/0198297556.001.0001

Zak, Paul J., and Stephen Knack. 2001. "Trust and Growth." Economic Journal 111 (470): 295-321. https://doi.org/10.1111/1468-0297.00609

Received on 05-05-2017

DOI: https://doi.org/10.6000/1929-7092.2017.06.40

(C) 2017 Hayakawa and Venieris; Licensee Lifescience Global.

This is an open access article licensed under the terms of the Creative Commons Attribution Non-Commercial License (http://creativecommons.org/licenses/by-nc/3.0/) which permits unrestricted, non-commercial use, distribution and reproduction in any medium, provided the work is properly cited. 